\title{
FACTORS ASSOCIATED WITH WELL WATER POLLUTION IN LENTENG VILLAGE, PAMEKASAN, EAST JAVA
}

\author{
Fifit Eka Furi Astutik, Misbaha \\ School of Health and Sciences Insan Unggul, Surabaya
}

\begin{abstract}
Background: World Health Organization reported that globally diarrhea causes $4 \%$ of all deaths. Diarrhea is most commonly caused by gastrointestinal infections which kill around 2.2 million people globally each year. Children in developing countries are most affected. Cholera and dysentery cause severe and sometime life threatening forms of diarrhea. The use of clean water is an important preventive measure. Otherwise the use of contaminated water may cause diarrhea. In 2015 it was estimated that approximately 2.1 billion people used unsafely managed drinking water. Of this, 423 million people took water from unprotected wells and springs. Health report showed that in 2016 there were 216 diarrhea cases in Lenteng village, Pamekasan, East Java. This study aimed to determine the factors associated with well water pollution in Lenteng villages, Pamekasan, East Java.
\end{abstract}

Subjects and Method: This was a cross sectional study conducted in Lenteng Village, Pamekasan, East Java, from February to June 2017. A sample of 60 household wells was selected for this study by random sampling. The dependent variable was well water pollution. The independent variables were the distance from the toilet and the number of well water users. Data were collected by questionnaire and direct observation. Water pollution was measured by laboratory. The data were analyzed by logistic regression.

Results: The risk of well water pollution increased with short distance to the toilet $(\mathrm{OR}=7.74,95 \% \mathrm{CI}=1.71$ to $35.01, \mathrm{p}=0.008)$. The risk of well water pollution decreased with fewer number of well water users $(\mathrm{OR}=0.13 ; 95 \% \mathrm{CI}=$ 0.31 to $0.58 ; \mathrm{p}=0.007$ ).

Conclusion: The risk of well water pollution increases with short distance to the toilet and decreases with fewer number of well water users.

Keywords: well water, pollution, distance to toilet, number of well water users

\section{Correspondence:}

Fifit Eka Furi Astutik. School of Health and Sciences Insan Unggul, Surabaya. Email: fefa.cantik@gmail.com. Mobile: +6281333337088. 